\title{
Mycosis Fungoides and Sezary Syndrome B2 TNM Finding v7
}

National Cancer Institute

\section{Source}

National Cancer Institute. Mycosis Fungoides and Sezary Syndrome B2 TNM Finding v7.

NCl Thesaurus. Code C88256.

High blood tumor burden: 1000/microL Sezary cells or more with positive clone. Note 1: for blood, Sezary cells are defined as lymphocytes with hyperconvoluted cerebriform nuclei. If Sezary cells are not able to be used to determine tumor burden for B2, then one of the following modified ISCL criteria along with a positive clonal rearrangement of the TCR may be used instead: (1) expanded CD4+ or CD3+ cells with CD4/CD8 ratio of 10 or more, (2) expanded CD4+ cells with abnormal immunophenotype including loss of CD7 or CD26. Note 2: A T-cell clone is defined by PCR or Southern blot analysis of the T-cell receptor gene. (from AJCC 7th Ed.) 